\title{
Perancangan Sistem Diagnosa Penyakit Campak Menggunakan Certainty Factor
}

\author{
Designing a System for Diagnosing Measles Using the Certainty Factor
}

\author{
I Wayan Rangga Pinastawa*1, Ema Utami ${ }^{2}$, Rudyanto Arief ${ }^{2}$ \\ 1,2,3 Universitas Amikom Yogyakarta \\ E-mail: *11wayan.pinastawa@astudents.amikom.ac.id, ${ }^{2}$ ema.u@amikom.ac.id, \\ ${ }^{2}$ rudy@amikom.ac.id
}

\begin{abstract}
Abstrak
Penyakit campak merupakan salah satu penyakit menular yang masih menjadi masalah kesehatan di Indonesia, karena sering dilaporkan dibeberapa daerah. Menurut data IDAI insiden campak pada balita sebesar 582/10.000. Metode yang digunakan adalah metode Certainty Factor atau Metode Kepastian. Tujuan penelitian ini adalah membuat perangkat lunak sistem pakar yang diharapkan dapat membantu masyarakat dalam mendiagnosa jenis penyakit campak dan rubella. Perangkat lunak sistem pakar ini meliputi analisis kebutuhan user, analisis kebutuhan sistem dan perancangan rekayasa pengetahuan dimana dalam pembuatan rekayasa perangkat lunak ini, data yang terkumpul direpresentasikan sebagai basis pengetahuan keputusan, basis aturan dan perancangan mesin inferensi, selanjutnya perancangan sistem, yang merancang pembuatan pemodelan proses yang terdiri usecase dan activity diagram, pemodelan data yang terdiri dari perancangan table, pengembangan proses selanjutnya adalah implementasi menggunakan berbasis website. Hasil penelitian berupa program aplikasi sistem pakar yang mampu mendiagnosa penyakit Campak. Keluaran sistem berupa hasil diagnosis meliputi tentang penyebab penyakit, penularan penyakit, pencegahan penyakit dan solusi penyakit campak pada anak. Dan juga dilengkapai dengan MB, MD dan nilai C.F yang diperoleh dengan perhitungan menggunakan metode Certainty Faktor.
\end{abstract}

Kata Kunci-Diagnosa, Campak, Rubella, Certainty Factor

\begin{abstract}
Measles is a contagious disease that is still a health problem in Indonesia, as often reported in some areas. According to data SKR (1996) the incidence of measles in infants at 582/10.000. The method used is the Certainty Factor method or methods Kepastian.Tujuan this research is to create a software expert system that is expected to assist the community in diagnosing type measles expert system software include user needs analysis, requirements analysis and system design engineering knowledge which in pmbuatan this software engineering, data collected represented as a knowledge base, decision, rule base and inference engine design, system design further, the design creation process use case and activity diagram, data modeling which consists of designing Table Mapping, designing go round the table next process inplementasi development using website based. The results in the form of an expert system application program that is able to diagnose diseases such as measles output system disease diagnosis include the value of MB and CF values obtained by calculation using the method of Certainty factors, causes and solutions.
\end{abstract}

Keywords-Diagnosis, Measles, Rubella, Certainty Factor 


\section{PENDAHULUAN}

\subsection{Latar Belakang Masalah}

Penyakit campak merupakan salah satu penyakit menular yang masih menjadi masalah kesehatan di Indonesia, karena sering dilaporkan dibeberapa daerah. Menurut data Ikatan Dokter Anak Indonesia (IDAI) insiden campak pada balita sebesar 582/10.000. Angka tersebut jauh lebih rendah dibanding tahun 2016 sebelum program imunisasi campak dimulai, yaitu sebesar 8000/10.000 pada anak umur 1-15 tahun imunisasi merupakan salah satu upaya terbaik untuk menurunkan insiden campak cenderung turun pada semua golongan umur. Pada bayi kurang dari 1 tahun dan anak umur 1-4 tahun terjadi penurunan cukup tajam, sedangkan pada golongan umur 5-14 tahun relative lambat [1]. Saat ini program pemberantasan penyakit campak dalam tahap reduksi yaitu penurunan jumlah kasus dan kematian akibat campak, menyusul tahap elminasi dan akhirnya tahap eradikasi. Diharapkan 10-15 tahun setelah eliminasi, penyakit campak dapat dieradikasi, karena satu-satunya pejamunya adalah manusia. Respon imun memegang peran penting dalam upaya mengatasi infeksi virus campak. Baik respon yang timbul oleh infeksi campak alam maupun respon setelah imunisasi. Program Pencegahan dan Pemberantasan Campak di Indonesia pada saat ini berada pada tahap reduksi dengan pengendalian dan pencegahan KLB. Hasil pemeriksaan sampel darah dan urine penderita campak pada saat KLB menunjukan Igm positif sekitar 70\% - 100\% [1]. CFR campak dari Rumah Sakit maupun dari hasil penyidikan KLB selama tahun 2015 - 2016 cenderung meningkat, kemungkinan hal ini terjadi berkaitan dengan dampak krisis pangan dan gizi, namun masih perlu dikaji secara mendalam dan comprehensive. Siding WHO tahun 2016, menetapkan kesepakatan global untuk membasmi polio atau Eradikasi Polio (Rapo), Eliminasi Tetanus Neonatorium (ETN) dan Reduksi Campak (RECAM) pada tahun 2017 [1]. Beberapa negara seperti Amerika, Australia dan beberapa negara lainnya telah memasuki tahap eliminasi campak. Pada siding CDC/PAHO/WHO tahun 2016 mnyimpulkan bahwa campak dimungkinkan untuk dieradikasi karena satu-satunya pejamu (host) atau reservoir campak hanya pada manusia dan adanya vaksin dengan potensi yang cukup tinggi dengan effikasi vaksin 85\% [1]. Diperkirakan eradikasi akan dapat dicapai 10 - 15 tahun setelah eliminasi. Program imunisasi campak di Indonesia dimulai pada tahun 2015 dan masuk dalam pengembangan program imunisasi. Pada tahun 2016, Indonesia dinyatakan telah mencapai UCI secara nasional. Dengan keberhasilan Indonesia mencapai UCI tersebut memberikan dampak positif terhadap kecenderungan penurunan insidens campak, khususnya pada balita dari 20,08/10.000 - 3,4/10.000 selama tahun 2016 - 2017 (ajusment data rutin SST). Walaupun imunisasi campak telah mencapai UCI namun dibeberapa daerah masih terjadi KLB campak, terutama di daerah dengan cakupan imunisasi rendah atau daerah kantong [1].

Oleh sebab itu dengan ditunjang kemajuan teknologi, maka dibutuhkan alat bantu yang dapat membantu tugas para dokter untuk mendiagnosa penyakit campak dengan menggunakan pendekatan teknologi. Disamping itu dapat meringankan beban dokter dalam menganalisis suatu gejala yang ditimbulkan oleh pasien. Sehingga dokter dapat lebih cepat dalam mendiagosa penyakit pasien [2].

Kemajuan teknologi saat ini telah berkembang pesat seiring dengan kemajuan dalam berbagai aspek kehidupan, salah satunya adalah komputer. Komputer merupakan salah satu teknologi yang berfungsi sebagai alat bantu yang dapat memberi kemudahan bagi manusia untuk memenuhi kebutuhan informasi yang diperlukan. Teknologi komputer dapat digunakan dalam berbagai bidang, salah satunya adalah bidang kesehatan [3].

Dalam bidang kesehatan telah banyak aplikasi komputer yang diciptakan untuk membantu efisiensi kerja. Salah satu aplikasi tersebut adalah sistem pakar yang merupakan salah satu kecerdasan buatan atau Artificial intelligent (AI). Sistem pakar (expert system) adalah sistem berbasis komputer yang menggunakan pengetahuan, fakta, dan teknik penalaran dalam memecahkan masalah yang biasanya hanya dapat dipecahkan oleh seorang pakar dalam bidang tersebut [4]. 
Umumnya pengetahuan diperoleh dari seorang pakar yang telah mempunyai pengalaman kerja selama bertahaun-tahun pada sebuah bidang keahlian tertentu. Sistem pakar mempunyai kemampuan untuk memecahkan maslah-masalah praktis saat sang pakar berhalangan. Knowledge (pengetahuan) dalam sistem pakar bisa dari seorang ahli, atau knowledge pada umumnya yang terdapat dalam buku, majalah, dan orang yang mempunyai pengetahuan tentang suatu bidang [5].

Sebagai tinjauan penelitian, dilakukan tinjuan pustaka sebagai dasar dan petunjuk dari penelitian yang akan dilakukan. Pada penelitian pertama menyebutkan bahwa, algoritma certainty factor dapat melakukan diagnosa dikarenakan metode ini memiliki probabilitas atau nilai dan tidak bertumpu pada rule saja sehingga tingkat kepercayaan lebih akurat dan cocok untuk mendiagnosa penyakit [5]. Pada peneliti kedua juga melakukan penelitian terkait metode certainty factor kemudian membandingkannya dengan metode certainty factor dan menunjukkan hasil bahwa metode certainty factor memiliki keakuratan sebesar 85\% sementara metode certainly factor hanya $80 \%$ berdasarkan kesesuaian hasil diagnosis sistem dan pakar, sehingga metode certainty factor lebih baik dapat dikatakan baik dalam mendiagnosis penyakit [6]. Pada penelitian yang dilakukan selanjutnya, menunjukkan bahwa metode certainty factor dapat memberikan pendekatan yang efektif untuk mengatasi kesalahan diagnosa [7].

Hal itulah yang menjadikan motivasi penulis untuk membuat suatu aplikasi yang dapat membantu memberikan solusi cepat dan tepat dalam mendiagnosa penyakit campak pada anak berdasarkan masalah-masalah yang dikeluhkan atau gejala yang diderita pasien dengan menggunakan metode certainty factor yaitu metode kepastian. Dalam penelitian ini penulis mengangkat judul "Perancangan Sistem Diagnosa Penyakit Campak".

\section{METODE PENELITIAN}

Penelitian yang akan dilakukan padapeneliti ini dilakukan dengan melakukan studi lapangan dan literatur menganai penyakit campak rubella dan sistem pakar serta metode algoritma Certainty Factor (CF). Dalam penelitian ini peneliti kan melakukan pengujian akurasi apakah sistem pakar dengan penerapan algoritma CF dapat memiliki akurasi baik dalam mengatasi masalah diagnosa campak rubella.

\subsection{Metode Penelitian}

Pendekatan yang dilakukan pada penelitian ini adalah melalui pendekatan dengan jenis kuantitatif, yaitu pendekatan penelitian ilmiah yang memiliki sifat sitematis yang terjadi terhadap suatu bagian dari fenomena berserta hubungannya. Tujuan dari pendekatan ini adalah menerapkan dan mengembangkan suatu model matematis, hipotesa dan/atau teori yang berkaitan dengan fenomena atau kejadian yang terlah terjadi.

Metode pengumpulan data pada penelitian yang akan dilakukan pada peneltian ini sebagai berikut:

1. Studi Lapangan (Sampel)

Merupakan metode pengumpulan data untuk mengambil sampel atau contoh-contoh. Pada penelitian menggunakan Teknik cluster sampling dimana sample akan diambil berdasarkan cluster atau daerah yaitu data pengidap penyakit rubella di daerah Yogyakarta yaitu 100 pasien pada tahun 2018.

2. Studi Pustaka

Peneliti akan melakukan pencarian studi pustaka untuk medapatkan informasi serta data-data yang berhubungan dengan masalah yang akan diteliti melaui berbagai sumber media yaitu buku, internet, jurnal, media cetak dan lainnya yang berkaitan dengan sistem pakar, metode certainty factor dan penyakit campak rubella. 
Citec Journal, Vol. 6, No. 2, Juli 2019

ISSN: 2354-5771

3. Wawancara

Wawancara dilakukan dengan Prof. Dr. ES Herini, SpA (K) selaku Ketua Komisi Eliminasi Campak \& Rubella Indonesia sebagai modal pengetahuan dan penaralan yang akan diterapkan dalam sistem yang akan dibuat.

\subsection{Metode Analisis Data}

Pada penelitin ini menggunakan data premier yang diperoleh dari studi lapangan melalui wawancara serta pengamatan langsung, serta data sekunder melalui sumber bacaan, dokumen resmi dari instansi kesehatan pemerintah. Data yang telah dikumpulkan tersebut akan dipadukan dengan pengetahuan dari pakar. Kemudian dijadikan pengetahuan untuk dimasukan kedalam sistem serta dijadikan sistem pakar melalui fakta atau pengetahuan dari data yang telah dikumpulkan tersebut.

\subsection{Alur Penelitian}

Alur penelitian ini berisikan diagram tentang detail alur atau langkah secara terperinci dan lengkap dari proses awal hingga akhir pada penelitian. Alur pada penelitian pada sistem diagnosa penyakit campak dan rubella dapat dilihat pada Gambar 2.

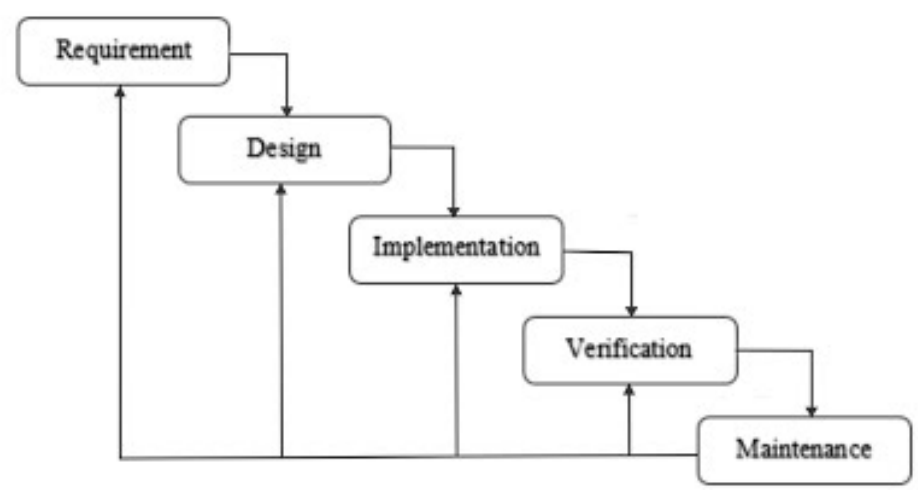

Gambar 2. Alur Metode Pengembangan Waterfall

Penjelasan secara singkat pada Gambar 2 atau alur metode pengambangan sistem waterfall yang akan digunakan dalam pembuatan sistem pakar penyakit campak dan rubella seperti berikut:

1. Requirement

Requirement merupakan tahap untuk melakukan literatur studi pada laporan, internet, artikel penelitian yang memiliki tema sejenis pada penelitian ini. Selanjutnya mengumpulkan data serta informasi melalui observasi langsung seperti wawancara dan dokumentasi dalam mencari data yang dibutuhkan.

2. Design

Design Planning merupakan tahap proses mendesain sebuah sistem melalui pembuatan model metode certainty factor, pemodelan proses Unified Modeling Language (UML), pemodelan data dengan entity relationship diagram (ERD) serta perancangan User Interface.

\section{HASIL DAN PEMBAHASAN}

\subsection{Perancangan Sistem}

Proses perancangan sistem akan dilakukan penggambaran suatu proses kebutuhan fungsional pada sistem yang akan dibuat dengan menggunakan usecase diagram seperti pada Gambar 3. Penggambaran alur diagnosa dengan menggunakan activity diagram untuk 
menjelaskan alur dalam tahap diagnosa pada sistem seperti yang terlihat pada Gambar 4. Kemudian perancangan pemodelan akan dilakukan dengan menggunakan relasi tabel pada database, sebagai gambaran arsitektur basis data yang akan diimplementasikan terlihat pada Gambar 5.

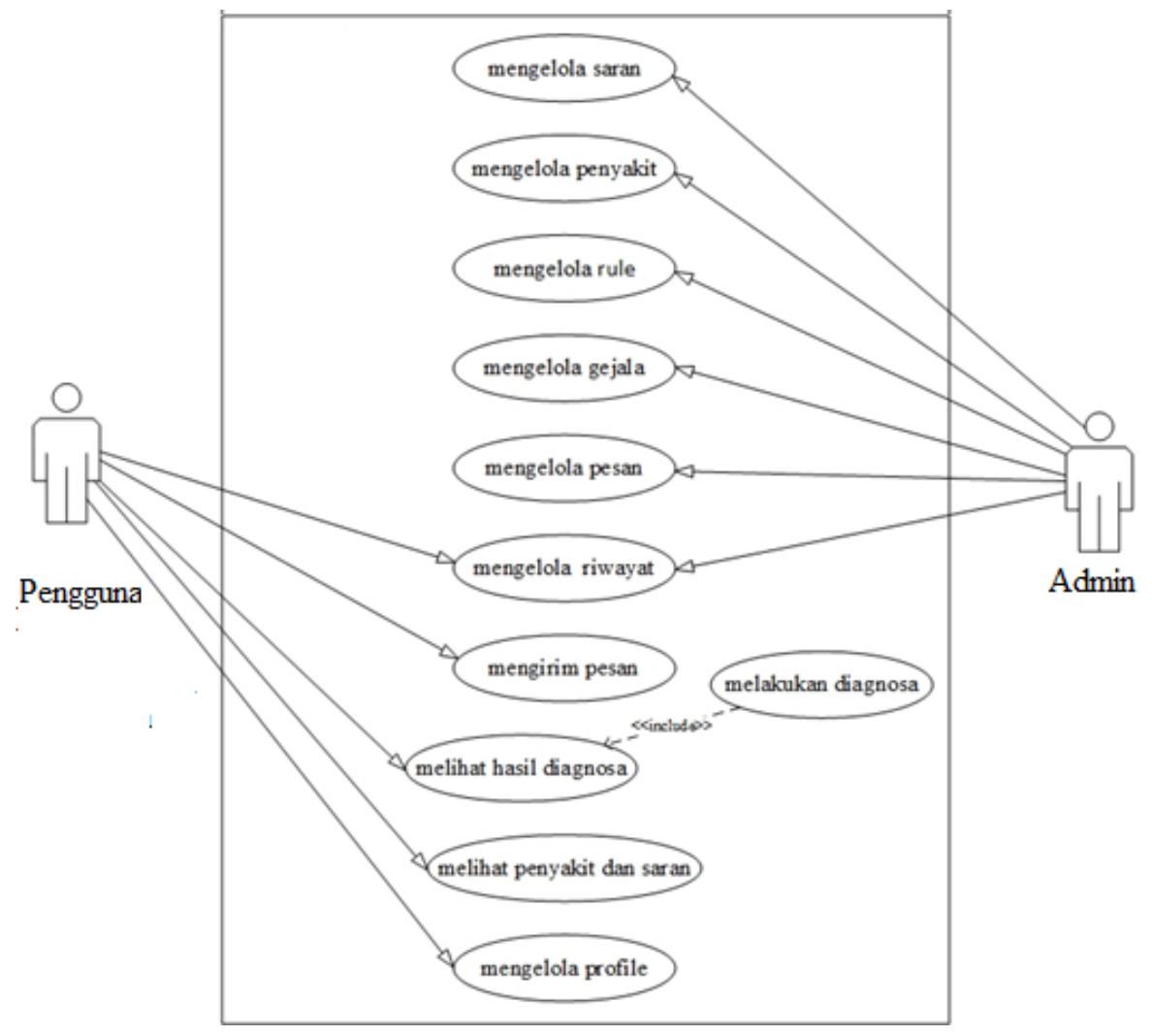

Gambar 3. Usecase Diagram

Usecase diagram pada Gambar 3 mejelaskan kebutuhan fungsional dari 2 aktor yaitu admin dan pengguna biasa. Sebagai admin terdapat fungsi mengelola saran, penyakit, rule, gejala, pesan dan riwayat. Sedangkan pengguna biasa dapat mengelola profile mereka, melihat penyakit dan saran penyakit, melakukan dan melihat hasil diagnosa serta melihat riwayat diagnosa dan mengirimkan pesan untuk admin atau pakar. Pada Gambar 3 juga dijelaskan bahwa ketika pengguna ingin melihat hasil diagnosa makan pengguna harus melakukan diagnosa terlebih dahulu dengan menginputkan gejala-gejala yang dialami oleh pengguna tersebut. 
Citec Journal, Vol. 6, No. 2, Juli 2019

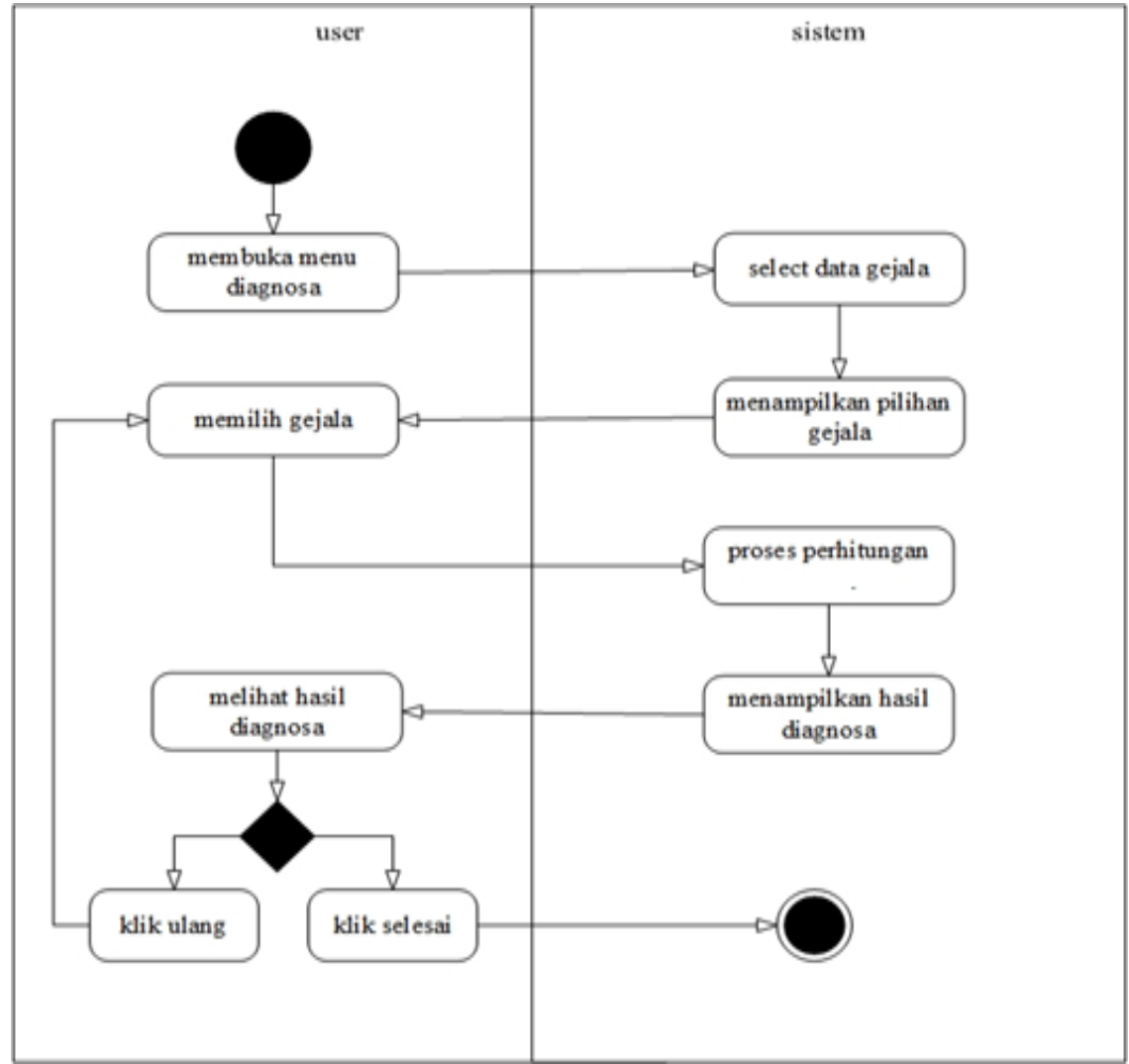

Gambar 4. Activity Diagram Diagnosa Penyakit

Activity Diagram pada Gambar 4 menerangkan alur diagnosa penyakit campak rubella dengan menggunakan metode CF. Pada gambar 4 juga dijalaskan bahwa pengguna atau user harus membuka menu diagnosa terlebih dahulu kemudian sistem akan melakukan respon untuk mencari data gejala pada penyakit campak dan rubella. Lalu sistem akan menampilkan daftar gejala yang akan dipilih oleh pengguna, setelah memilih gejala yang dialami makan sistem akan melakukan perhitungan dengan menggunakan metode CF untuk mendapatkan hasil diagnosa berdasarkan gejala yang dipilih sebelumnya. Setelah sistem mendapatkan hasil pengguna diberi pilihan untuk menyelesaikan proses tersebut atau melakukan diagnosa ulang.

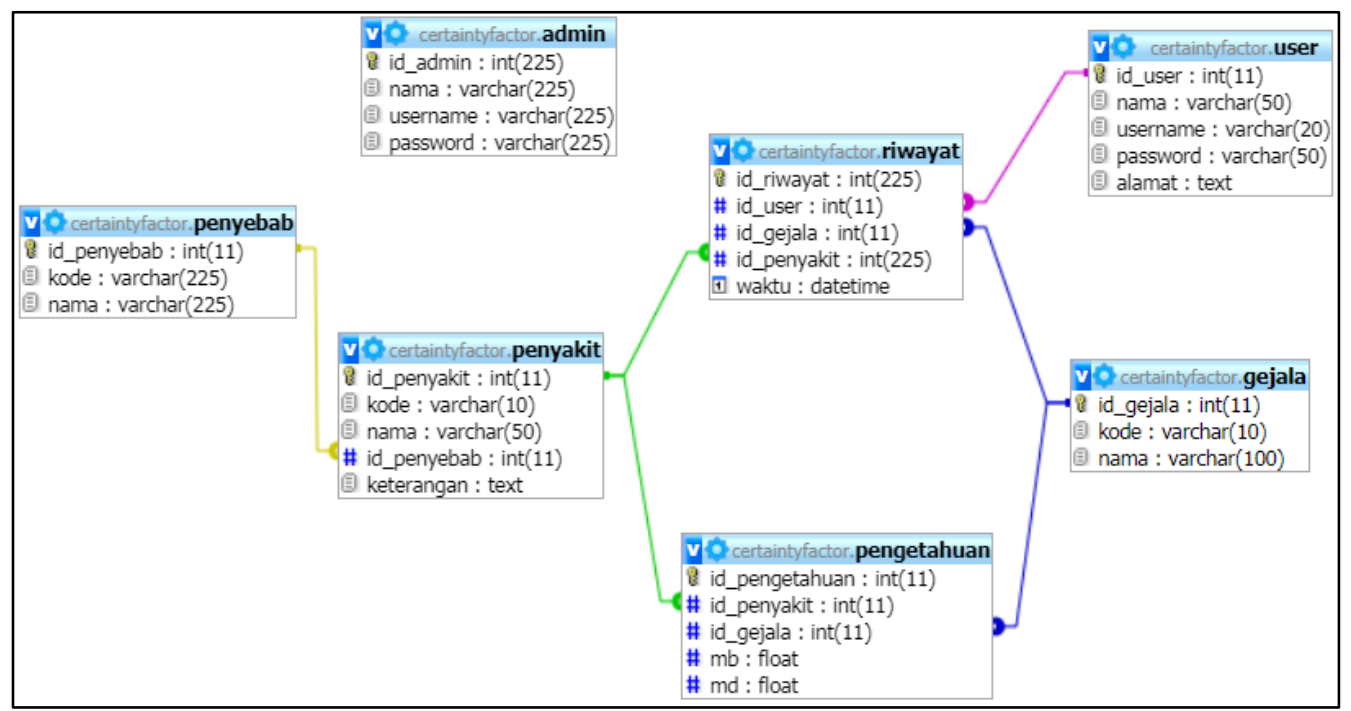

Gambar 5. Relasi Antar Tabel 
Relasi antar tabel pada Gambar 5 merupakan rancangan model yang akan diterapkan dalam database system. Rancangan tersebut berisi 7 tabel yaitu: admin untuk menyimpan data admin, user untuk menyimpan data user yang akan menggunakan sistem, gejala untuk menyimban data gejala, penyakit untuk menyimpan data penyakit, penyebab untuk menyimpan data penyebab dari setiap penyakit, riwayat berisikan data gejala dan hasil diagnosa penyakit yang telah dilakukan oleh user serta pengetahuan yang berisikan pengetahuan serta aturan penalaran diagnosis penyakit dari pakar penyakit campak dan rubella.

\subsection{Analisis Model Data dan Pengetahuan}

Analisis model data dan pengetahuan dilakukan dengan tujuan mendapatkan sebuah model algoritma CF berdasarkan pengetahuan dan tingkat kepercayaan dari pakar yaitu Prof. DR. ES Herini, SpA (K). data yang akan digunakan dan diterapkan untuk melakukan diagnosis penyakit adalah sebagai berikut:

1. Penyakit Campak pada anak, berisi data jenis penyakit Campak pada anak

2. Penyakit yang sejenis dengan penyakit campak (Rubella dan Roseola Infantum) berisi data penyakit yang sejenis dengan penyakit camapak pada anak.

3. Gejala, berisi data gejala yang menjadi dasar diagnosis suatu penyakit.

4. Solusi, berisi data solusi yang dapat diberikan kepada penderita, jika didiagnopsa menderita sustu penyakit.

Tabel 1. Pengetahuan Penyakit

\begin{tabular}{|l|l|}
\hline Kode Penyakit & \multicolumn{1}{c|}{ Nama Penyakit } \\
\hline PK0001 & Campak Stadium Kataral (Pradromal) \\
\hline PK0002 & Campak Stadium Erupsi \\
\hline PK0003 & Campak Konvalesensi \\
\hline PK0004 & Rubella (Camoak Jerman) \\
\hline PK0005 & Roseola Infantum \\
\hline
\end{tabular}

Pada Tabel 1 Merupakan daftar kode dan penyakit dari penyakit campak dan rubella didaerah Yogyakarta. Sedangkan data gejala yang terdapat pada jenis penyakit campak dan rubella, dapat dilihat pada Tabel 2.

Tabel 2. Pengetahuan Gejala

\begin{tabular}{|l|l|}
\hline Kode Gejala & \multicolumn{1}{|c|}{ Nama Gejala } \\
\hline G0001 & Demam \\
\hline G0002 & Batuk \\
\hline G0003 & Pilek \\
\hline G0004 & Diare dan Muntah \\
\hline G0005 & Muka Sembab \\
\hline G0006 & Sakit Tenggorokan \\
\hline G0007 & Rewel dan mudah tersinggung \\
\hline G0008 & $\begin{array}{l}\text { Ruam/kemerahan kulit selama 3 hari, pada mula ruam timbul diwajah } \\
\text { dan leher lalu menyebar ke batang badan lengan dan tungkai }\end{array}$ \\
\hline G0009 & Fotofobia(takut cahaya) \\
\hline G0010 & Konjungtivis (mata merah) \\
\hline G0011 & Rasa Gatal \\
\hline G0012 & Timbul Bercak Koplik \\
\hline G0013 & Disertai Pembengkakan Kelenjar Getah Bening Pda Kepala/Leher \\
\hline G0014 & Kulit Bersisik \\
\hline G0015 & Ruam Menjadi Hitam dan Mengelupas \\
\hline G0016 & Nyeri Sendi \\
\hline
\end{tabular}


Citec Journal, Vol. 6, No. 2, Juli 2019

ISSN: 2354-5771

\begin{tabular}{|l|l|}
\hline G0017 & Ruam Muncul Setelah Demam Turun \\
\hline G0018 & Kejang \\
\hline G0019 & Timpa Membesar \\
\hline G0020 & Tidak Terdapat Nyeri Tenggorokan, tapi Tenggorokan Agak Merah. \\
\hline
\end{tabular}
campak.

Tabel 3 menyajikan data tentang gejala yang memiliki nilai MB dan MD jenis penyakit

Tabel 3. Gejala yang memiliki nilai MB dan nilai MD

\begin{tabular}{|c|c|c|c|c|c|c|c|c|c|c|}
\hline \multirow{3}{*}{$\begin{array}{l}\text { Kode } \\
\text { Gejala }\end{array}$} & \multicolumn{6}{|c|}{ Campak } & \multirow{2}{*}{\multicolumn{2}{|c|}{$\begin{array}{c}\text { Rubella } \\
\text { (Campak } \\
\text { Jerman) }\end{array}$}} & \multirow{2}{*}{\multicolumn{2}{|c|}{$\begin{array}{l}\text { Roseola } \\
\text { Infantum }\end{array}$}} \\
\hline & \multicolumn{2}{|c|}{$\begin{array}{c}\text { Campak } \\
\text { Stadium } \\
\text { Kataral } \\
\text { (pradromal) }\end{array}$} & \multicolumn{2}{|c|}{$\begin{array}{c}\text { Campak } \\
\text { Stadium } \\
\text { Erupsi }\end{array}$} & \multicolumn{2}{|c|}{$\begin{array}{c}\text { Campak } \\
\text { Konvalesensi }\end{array}$} & & & & \\
\hline & MB & MD & MB & MD & MB & MD & MB & MD & MB & MD \\
\hline G0001 & 0,80 & 0,40 & 0,90 & 0,40 & 0,70 & 0,35 & 0,66 & 0,28 & 0,74 & 0,36 \\
\hline G0002 & 0,80 & 0,35 & 0,75 & 0,20 & 0,25 & 0,20 & 0,30 & 0,10 & 0,03 & 0,10 \\
\hline G0003 & 0,70 & 0,40 & 0,70 & 0,30 & 0,20 & 0,05 & 0,25 & 0,15 & 0,40 & 0,15 \\
\hline G0004 & 0,50 & 0,30 & 0,60 & 0,05 & 0,15 & 0,10 & 0,10 & 0,05 & 0,20 & 0,40 \\
\hline G0005 & 0,80 & 0,10 & 0,60 & 0,20 & 0,01 & 0,20 & 0,40 & 0,20 & 0,15 & 0,30 \\
\hline G0006 & 0,55 & 0,35 & 0,50 & 0,50 & 0,20 & 0,10 & 0,22 & 0,10 & 0,05 & 0,20 \\
\hline G0007 & 0,60 & 0,30 & 0,70 & 0,40 & 0,60 & 0,34 & 0,60 & 0,41 & 0,60 & 0,40 \\
\hline G0008 & 0,70 & 0,40 & 0,70 & 0,50 & 0,70 & 0,47 & 0,90 & 0,48 & 0,80 & 0,40 \\
\hline G0009 & 0,75 & 0,10 & 0,10 & 0,15 & 0,10 & 0,10 & 0,15 & 0,05 & 0,10 & 0,10 \\
\hline G0010 & 0,80 & 0,05 & 0,10 & 0,10 & 0,20 & 0,05 & 0,10 & 0,30 & 0,23 & 0,37 \\
\hline G0011 & 0,40 & 0,10 & 0,85 & 0,30 & 0,05 & 0,10 & 0,25 & 0,10 & 0,07 & 0,15 \\
\hline G0012 & 0,25 & 0,40 & 0,80 & 0,15 & 0,30 & 0,20 & 0,35 & 0,15 & 0,20 & 0,10 \\
\hline G0013 & 0,10 & 0,10 & 0,85 & 0,30 & 0,40 & 0,20 & 0,80 & 0,05 & 0,64 & 0,10 \\
\hline G0014 & 0,30 & 0,10 & 0,05 & 0,01 & 0,80 & 0,01 & 0,20 & 0,25 & 0,37 & 0,22 \\
\hline G0015 & 0,15 & 0,30 & 0,20 & 0,05 & 0,90 & 0,01 & 0,10 & 0,05 & 0,20 & 0,20 \\
\hline G0016 & 0,40 & 0,10 & 0,40 & 0,05 & 0,40 & 0,25 & 0,32 & 0,15 & 0,10 & 0,10 \\
\hline G0017 & 0,10 & 0,10 & 0,30 & 0,15 & 0,20 & 0,10 & 0,30 & 0,10 & 0,90 & 0,01 \\
\hline G0018 & 0,80 & 0,30 & 0,30 & 0,50 & 0,15 & 0,20 & 0,15 & 0,10 & 0,75 & 0,01 \\
\hline G0019 & 0,10 & 0,10 & 0,30 & 0,20 & 0,10 & 0,10 & 0,10 & 0,20 & 0,65 & 0,10 \\
\hline G0020 & 0,10 & 0,10 & 0,10 & 0,20 & 0,05 & 0,10 & 0,85 & 0,04 & 0,30 & 0,10 \\
\hline
\end{tabular}

\subsection{Analisis Implementasi Algoritma}

Cara penentukan jenis penyakit pada anak menggunakan metode kepastian atau CF, dengan rumus sebagai berikut.

a. Untuk mencari ukuran kepercayaan suatu penyakit yang dipengaruhi oleh suatu gejala adalah:

$$
\mathrm{MB}\left[\mathrm{h}, e_{1} \wedge e_{2}\right]=\mathrm{MB}\left[\mathrm{h}, e_{1}\right]+\mathrm{MB}\left[\mathrm{h}, e_{2}\right] .\left(1-\mathrm{MB}\left[\mathrm{h}, e_{1}\right]\right)
$$

b. Untuk mencari ukuran ketidakpercayaan suatu penyakit yang dipengaruhi oleg suatu gejala adalah:

$$
\operatorname{MD}\left[h, e_{1} \wedge e_{2}\right]=\operatorname{MD}\left[h, e_{1}\right]+\operatorname{MD}\left[h, e_{2}\right] .\left(1-M D\left[h, e_{1}\right]\right)
$$

Diberikan sebuah contoh kasus diagnosis dengan data dan aturan dari hasil penelitian. Diandaikan sistem meliliki 3 aturan sebagaimana ditunjukkan dalam Tabel 4. 
Tabel 4. Contoh Aturan Diagnosa

\begin{tabular}{|c|c|c|c|c|}
\hline $\begin{array}{c}\text { Kode } \\
\text { Penyakit }\end{array}$ & Penyakit & Gejala & MB & MD \\
\hline AP001 & $\begin{array}{l}\text { Campak Stadium } \\
\text { Kataral }\end{array}$ & Demam & 0.8 & 0.4 \\
\hline AP002 & $\begin{array}{l}\text { Campak Stadium } \\
\text { Erupsi }\end{array}$ & Demam & 0.9 & 0.4 \\
\hline AP003 & $\begin{array}{l}\text { Campak Stadium } \\
\text { Konvalensi }\end{array}$ & Demam & 0.7 & 0.35 \\
\hline AP004 & Rubeolla & Demam & 0.66 & 0.28 \\
\hline AP005 & Roseola Infantum & Demam & 0.74 & 0.36 \\
\hline AP006 & $\begin{array}{l}\text { Campak Stadium } \\
\text { Kataral }\end{array}$ & Diare dan Muntah & 0.5 & 0.3 \\
\hline AP007 & $\begin{array}{l}\text { Campak Stadium } \\
\text { Erupsi }\end{array}$ & Diare dan Muntah & 0.6 & 0.05 \\
\hline AP008 & $\begin{array}{l}\text { Campak Stadium } \\
\text { Kataral }\end{array}$ & $\begin{array}{l}\text { Ruam / kemerahan kulit selama } 3 \text { hari pada } \\
\text { mula ruam timbul di wajah dan leher lalu } \\
\text { menyebabr ke batang badan lengan dan } \\
\text { tungkai,dandisertaipembengkakan kelenjar } \\
\text { getah bening pada kelapa / leher. }\end{array}$ & 0.7 & 0.4 \\
\hline AP009 & $\begin{array}{l}\text { Campak Stadium } \\
\text { Erupsi }\end{array}$ & $\begin{array}{l}\text { Ruam / kemerahan kulit selama } 3 \text { hari pada } \\
\text { mula ruam timbul di wajah dan leher lalu } \\
\text { menyebabr ke batang badan lengan dan } \\
\text { tungkai,dandisertaipembengkakan kelenjar } \\
\text { getah bening pada kelapa / leher. }\end{array}$ & 0.7 & 0.5 \\
\hline AP010 & $\begin{array}{l}\text { Campak Stadium } \\
\text { Konvalensi }\end{array}$ & $\begin{array}{l}\text { Ruam / kemerahan kulit selama } 3 \text { hari pada } \\
\text { mula ruam timbul di wajah dan leher lalu } \\
\text { menyebabr ke batang badan lengan dan } \\
\text { tungkai,dandisertaipembengkakan kelenjar } \\
\text { getah bening pada kelapa / leher. }\end{array}$ & 0.7 & 0.47 \\
\hline AP011 & Rubeolla & $\begin{array}{l}\text { Ruam / kemerahan kulit selama } 3 \text { hari pada } \\
\text { mula ruam timbul di wajah dan leher lalu } \\
\text { menyebabr ke batang badan lengan dan } \\
\text { tungkai,dandisertaipembengkakan kelenjar } \\
\text { getah bening pada kelapa / leher. }\end{array}$ & 0.90 & 0.48 \\
\hline AP012 & $\begin{array}{l}\text { Roseolla } \\
\text { Infantum }\end{array}$ & $\begin{array}{l}\text { Ruam / kemerahan kulit selama } 3 \text { hari pada } \\
\text { mula ruam timbul di wajah dan leher lalu } \\
\text { menyebabr ke batang badan lengan dan } \\
\text { tungkai dan disertai pembengkakan kelenjar } \\
\text { getah bening pada kelapa / leher. }\end{array}$ & 0.8 & 0.4 \\
\hline
\end{tabular}

Untuk lebih jelasnya dapat dilihat contoh kasus tentang penyakit campak pada anak sebaagi berikut.

Pada contoh kasus konsultasi ini, pengguna memilih 3 gejala yang dirasakan yaitu pengguna merasakan demam, batuk, ruam / kemerahan kulit selama 3 hari. Pada awalnya ruam timbul diwajah dan leher lalu menyebar ke batang badan lengan dan tungkai. Selanjutnya, disertai pembengkakan kelenjar getah bening pada kepala/leher. Hasil perhitungan sistem setelah membanding nilai CF masing-masing penyakit terdapat nilai CF yang terbesar yaitu penyakit Rubella dengan nilai CF terbesar 0,3404. Berikut adalah perhitungan manual dengan metode CF, diketahui: 
1. G0001 (Demam), merupakan gejala yang dimiliki oleh penyakit Campak Stadium Kataral (PK0001), Campak Stadium Erupsi (PK0002), Campak Stadium Konvalensi (PK0003), Rubella (PK0004), Roseola Infantum (PK0005).

2. G0002 (Diare dan Muntah), merupakan gejala yang dimiliki oleh penyakit Campak Stadium Kataral (PK0001), Campak Stadium Erupsi (PK0002).

3. G0008 (Ruam / kemerahan kulit selama 3 hari pada mula ruam timbul diwajah dan leher lalu menyebabr ke batang badan lengan dan tungkai) merupakan gejala yang dimiliki oleh penyakit Campak Stadium Kataral (PK0001), Campak Stadium Erupsi (PK0002), Campak Stadium Konvalensi (PK0003), Rubella (PK0004), Roseola Infantum (PK0005).

\section{Perhitungan Manual}

1. Campak Stadium Kataral (P0001)

a) $\mathrm{G} 0001 \rightarrow \mathrm{MB}=0,80, \quad \mathrm{MD}=0,40$

b) $\mathrm{G} 0004 \rightarrow \mathrm{MB}=0,50, \quad \mathrm{MD}=0,30$

$$
\begin{aligned}
\mathrm{MB}\left[\mathrm{h}, e_{1} \wedge e_{2}\right] & =\mathrm{MB}\left[\mathrm{h}, e_{1}\right]+\mathrm{MB}\left[\mathrm{h}, e_{2}\right] \cdot\left(1-\mathrm{MB}\left[\mathrm{h}, e_{1}\right]\right) \\
& =0,80+0,50 *(1-0,80) \\
& =0,80+0,50 *(0,20) \\
& =0,80+0,1=\mathbf{0 , 9} \\
& =\operatorname{MD}\left[\mathrm{h}, \mathrm{e}_{1}\right]+\operatorname{MD}\left[\mathrm{h}, \mathrm{e}_{2}\right] \cdot\left(1-\mathrm{MD}\left[\mathrm{h}, \mathrm{e}_{1}\right]\right) \\
& =0,40+0,30 *(1-0,40) \\
& =0,40+0,30 *(0,60) \\
& =0,40+0,18=\mathbf{0 , 5 8}
\end{aligned}
$$

c) $\mathrm{G0008} \rightarrow \mathrm{MB}=0,70, \mathrm{MD}=0,40$

$$
\begin{aligned}
\mathrm{MB}\left[\mathrm{h}, e_{1} \wedge e_{2}\right] & =\mathrm{MB}\left[\mathrm{h}, e_{1}\right]+\mathrm{MB}\left[\mathrm{h}, e_{2}\right] \cdot\left(1-\mathrm{MB}\left[\mathrm{h}, e_{1}\right]\right) \\
& =0,9+0,70 *(1-0,9) \\
& =0,9+0,70 *(0,1) \\
& =0,9+0,07=\mathbf{0 , 9 7} \\
\mathrm{MD}\left[\mathrm{h}, \mathrm{e}_{1} \wedge \mathrm{e}_{2}\right] & =\mathrm{MD}\left[\mathrm{h}, \mathrm{e}_{1}\right]+\mathrm{MD}\left[\mathrm{h}, \mathrm{e}_{2}\right] \cdot\left(1-\mathrm{MD}\left[\mathrm{h}, \mathrm{e}_{1}\right]\right) \\
& =0,58+0,40 *(1-0,58) \\
& =0,58+0,40 *(0,42) \\
& =0,58+0,168=\mathbf{0 , 7 4 8} \\
\mathrm{CF}[\mathrm{h}, \mathrm{e}] & =\mathrm{MB}[\mathrm{h}, \mathrm{e}]-\mathrm{MD}[\mathrm{h}, \mathrm{e}] \\
& =0,97-0,748 \\
& =\mathbf{0 , 2 2 2}
\end{aligned}
$$

2. Campak Stadium Erupsi (P0002)

a) $\mathrm{G} 0001 \rightarrow \mathrm{MB}=0,90, \mathrm{MD}=0,40$

b) $\mathrm{G} 0002 \rightarrow \mathrm{MB}=0,60, \mathrm{MD}=0,05$

$$
\begin{aligned}
\operatorname{MB}\left[\mathrm{h}, e_{1} \wedge e_{2}\right] \quad= & \operatorname{MB}\left[\mathrm{h}, e_{1}\right]+\mathrm{MB}\left[\mathrm{h}, e_{2}\right] \cdot\left(1-\mathrm{MB}\left[\mathrm{h}, e_{1}\right]\right) \\
& =0,90+0,60 *(1-0,90) \\
& =0,90+0,60 *(0,10) \\
& =0,90+0,06=\mathbf{0 , 9 6} \\
= & \operatorname{MD}\left[\mathrm{h}, \mathrm{e}_{1}\right]+\operatorname{MD}\left[\mathrm{h}, \mathrm{e}_{2}\right] \cdot\left(1-\mathrm{MD}\left[\mathrm{h}, \mathrm{e}_{1}\right]\right) \\
& =0,40+0,05 *(1-0,40) \\
& =0,40+0,05 *(0,60) \\
& =0,40+0,03=\mathbf{0 , 4 3}
\end{aligned}
$$

c) $\mathrm{G} 0008 \rightarrow \mathrm{MB}=0,70, \mathrm{MD}=0,50$

$$
\begin{aligned}
& \mathrm{MB}\left[\mathrm{h}, e_{1} \wedge e_{2}\right]=\mathrm{MB}\left[\mathrm{h}, e_{1}\right]+\mathrm{MB}\left[\mathrm{h}, e_{2}\right] .\left(1-\mathrm{MB}\left[\mathrm{h}, e_{1}\right]\right) \\
& =0,96+0,70 *(1-0,96) \\
& =0,96+0,70 *(0,04) \\
& =0,96+0,028=\mathbf{0 , 9 8 8}
\end{aligned}
$$




$$
\begin{aligned}
& =0,43+0,50 *(1-0,43) \\
& =0,43+0,50 *(0,57) \\
& =0,43+0,285=\mathbf{0 , 7 1 5} \\
\mathrm{CF}[\mathrm{h}, \mathrm{e}] & =\mathrm{MB}[\mathrm{h}, \mathrm{e}]-\mathrm{MD}[\mathrm{h}, \mathrm{e}] \\
& =0,988-0,715 \\
& =\mathbf{0 , 2 7 3}
\end{aligned}
$$

3. Campak Stadium Konvalensi (P0003)

a) $\mathrm{G} 0001 \rightarrow \mathrm{MB}=0,70, \mathrm{MD}=0,35$

b) $\mathrm{G} 0008 \rightarrow \mathrm{MB}=0,70, \mathrm{MD}=0,47$

$\mathrm{MB}\left[\mathrm{h}, e_{1} \wedge e_{2}\right]=\mathrm{MB}\left[\mathrm{h}, e_{1}\right]+\mathrm{MB}\left[\mathrm{h}, e_{2}\right] .\left(1-\mathrm{MB}\left[\mathrm{h}, e_{1}\right]\right)$

$$
\begin{aligned}
& =0,70+0,70 *(1-0,30) \\
& =0,70+0,70 *(0,30)
\end{aligned}
$$$$
=0,70+0,21=\mathbf{0 , 9 1}
$$

$\operatorname{MD}\left[h, e_{1} \wedge e_{2}\right]=M D\left[h, e_{1}\right]+M D\left[h, e_{2}\right] .\left(1-M D\left[h, e_{1}\right]\right)$

$$
\begin{aligned}
& =0,35+0,47 *(1-0,35) \\
& =0,35+0,47 *(0,65)
\end{aligned}
$$$$
=0,35+0,3055=\mathbf{0 6 5 5 5}
$$

$\mathrm{CF}[\mathrm{h}, \mathrm{e}]=\mathrm{MB}[\mathrm{h}, \mathrm{e}]-\mathrm{MD}[\mathrm{h}, \mathrm{e}]$

$=0,91-0,6555$

$=0,2545$

4. Rubella (Campak Jerman) (P0004)

1) $\mathrm{G} 0001 \rightarrow \mathrm{MB}=0,66, \mathrm{MD}=0,28$

2) $\mathrm{G} 0008 \rightarrow \mathrm{MB}=0,90, \mathrm{MD}=0,48$

$\mathrm{MB}\left[\mathrm{h}, e_{1} \wedge e_{2}\right]=\mathrm{MB}\left[\mathrm{h}, e_{1}\right]+\mathrm{MB}\left[\mathrm{h}, e_{2}\right] \cdot\left(1-\mathrm{MB}\left[\mathrm{h}, e_{1}\right]\right)$

$$
=0,66+0,90 *(1-0,66)
$$$$
=0,66+0,90 *(0,34)
$$$$
=0,66+0,306=\mathbf{0 , 9 6 6}
$$

$\operatorname{MD}\left[h, e_{1} \wedge e_{2}\right]=M D\left[h, e_{1}\right]+M D\left[h, e_{2}\right] .\left(1-M D\left[h, e_{1}\right]\right)$

$=0,28+0,48 *(1-0,28)$

$=0,28+0,48 *(0,72)$

$=0,28+0,3456=\mathbf{0 , 6 2 5 6}$

5. Roseolla Infantum (P0005)

$\mathrm{CF}[\mathrm{h}, \mathrm{e}]=\mathrm{MB}[\mathrm{h}, \mathrm{e}]-\mathrm{MD}[\mathrm{h}, \mathrm{e}]$

$=0,966-0,6256$

$$
=0,3404
$$

1) $\mathrm{G} 0001 \rightarrow \mathrm{MB}=0,74, \mathrm{MD}=0,36$

2) $\mathrm{G} 0008 \rightarrow \mathrm{MB}=0,80, \mathrm{MD}=0,40$

$\mathrm{MB}\left[\mathrm{h}, e_{1} \wedge e_{2}\right]=\mathrm{MB}\left[\mathrm{h}, e_{1}\right]+\mathrm{MB}\left[\mathrm{h}, e_{2}\right] \cdot\left(1-\mathrm{MB}\left[\mathrm{h}, e_{1}\right]\right)$

$$
\begin{aligned}
& =0,74+0,80 *(1-0,74) \\
& =0,74+0,80 *(0,26)
\end{aligned}
$$$$
=0,74+0,208
$$

$$
=\mathbf{0 , 9 4 8}
$$

$\operatorname{MD}\left[\mathrm{h}, \mathrm{e}_{1} \wedge \mathrm{e}_{2}\right]=\operatorname{MD}\left[\mathrm{h}, \mathrm{e}_{1}\right]+\mathrm{MD}\left[\mathrm{h}, \mathrm{e}_{2}\right] .\left(1-\mathrm{MD}\left[\mathrm{h}, \mathrm{e}_{1}\right]\right)$

$=0,36+0,40 *(1-0,36)$

$=0,36+0,40 *(0,64)$

$=0,36+0,256=\mathbf{0 , 6 1 6}$

$\mathrm{CF}[\mathrm{h}, \mathrm{e}] \quad=\mathrm{MB}[\mathrm{h}, \mathrm{e}]-\mathrm{MD}[\mathrm{h}, \mathrm{e}]$

$=0,948-0,616$

$=0,332$ 
Citec Journal, Vol. 6, No. 2, Juli 2019

\subsection{Pengujian Sistem}

Pada bagian ini akan dibandingkan hasil analisa diagnosis penyakit campak dan rubella pada anak menggunakan sistem pakar dan diagnosis dari dokter atau pakar yang sesungguhnya.

Tabel 5. Hasil Pengujian Sistem

\begin{tabular}{|c|c|c|c|c|}
\hline \multirow[t]{2}{*}{ NO } & \multirow[t]{2}{*}{ Kasus } & \multicolumn{2}{|c|}{ Hasil Diagnosa } & \multirow[t]{2}{*}{ Pembahasan } \\
\hline & & Pakar & Sistem & \\
\hline 1 & $\begin{array}{l}\text { Gejala: } \\
\text { Demam, Batuk, Ruam/kemerahan kulit } \\
\text { selama } 3 \text { hari, pada mula ruam timbul } \\
\text { diwajah dan leher. lalu menyebar ke } \\
\text { batang lengan dan tungkai, Diare dan } \\
\text { muntah, Nyeri Sendi, Disertai } \\
\text { pembengkakan kelenjar getah bening pada } \\
\text { kepala dan leher, Rewel dan mudah } \\
\text { tersinggung }\end{array}$ & $\begin{array}{l}\text { Campak } \\
\text { Stadium } \\
\text { Erupsi }\end{array}$ & $\begin{array}{l}\text { Rubella, } \\
\mathrm{CF}=0,207\end{array}$ & Tidak Benar \\
\hline 2 & $\begin{array}{l}\text { Gejala: } \\
\text { Demam, Timbul bercak kolpik, Nyeri } \\
\text { sendi, Batuk }\end{array}$ & $\begin{array}{l}\text { Campak } \\
\text { Stadium } \\
\text { Erupsi }\end{array}$ & $\begin{array}{l}\text { Campak } \\
\text { Stadium } \\
\text { Erupsi, CF } \\
=0,377\end{array}$ & Benar \\
\hline 3 & $\begin{array}{l}\text { Gejala: } \\
\text { Demam, Disertai pembengkakan kelenjar } \\
\text { getah bening pada kepala dan leher, } \\
\text { Timbul bercak kolpik, Rasa gatal, Muka } \\
\text { sembab }\end{array}$ & $\begin{array}{l}\text { Campak } \\
\text { Stadium } \\
\text { Erupsi }\end{array}$ & $\begin{array}{l}\text { Rubella, } \\
\text { CF }=0,398\end{array}$ & Tidak Benar \\
\hline$\ldots . .$. & ....... & ....... & ...... & ......... \\
\hline 25 & $\begin{array}{l}\text { Gejala: } \\
\text { Demam, Disertai pembengkakan kelenjar } \\
\text { getah bening pada kepala dan leher, Ruam } \\
\text { muncul setelah demam turun, Kejang }\end{array}$ & Rubella & $\begin{array}{l}\text { Rubella, } \\
\text { CF =0,513 }\end{array}$ & Benar \\
\hline
\end{tabular}

Berdasarkan hasil pada Tabel 5 dengan jumlah 20 kasus pengujian yang dilakukan oleh sistem dan pakar maka didapatkan hasil 23 kasus benar dan 2 kasus kurang tepat sehingga dapat dirumuskan sebagai berikut.

$$
\text { Perbandingan Hasil Diagnosa }(\%)=\frac{23}{25} \times 100 \%=92 \%
$$

\section{KESIMPULAN}

Setelah melalui tahap pengujian pada sistem pakar diagnosa penyakit campak dan rubella menggunakan certainty faktor, maka dapat diambil sebuah kesimpulan telah berhasil dibangun sebuah sistem pakar untuk mendiagnosa penyakit campak dan rubella berserta saran atau solusi penanggulangan penyakit tersebut dengan nilai akurasi pengujian 92\%.

\section{SARAN}

Saran yang dapat dilakukan untuk mengoptimalkan maupun mengembangkan sistem antara lain:

1. Adanya pengembangan ruang lingkup sistem lebih lanjut, misalnya dengan menambahkan hasil pemeriksaan laboratorium 
2. Adanya update data minimal setiap 6 bulan untuk memperoleh informasi terbaru tentang penyakit untuk hasil yang lebih valid.

3. Sistem pakar ini dapat dikembangkan lagi dengan menggabungkan dengan metode lain untuk mendapatkan hasil yang lebih valid.

4. Sistem pakar diagnosa penyakit campak dan rubella ini dapat dikembangkan menjadi aplikasi berbasis mobile yang terintegrasi dengan website sistem pakar diagnosa penyakit campak dan rubella.

\section{DAFTAR PUSTAKA}

[1] Kementrian Kesehatan Republik Indonesia, 2019, Keputusan Menteri Kesehatan (KEMENKES) Republik Indonesia Nomor-856 tentang Pedoman Pengendalian Terhadap Anak, Sekretariat Negara, Jakarta.

[2] Septiandika, V. M., Lusiana, D., 2017, Diagnosa Penyakit Campak Pada Anak dengan Penerapan Metode Naïve Bayes, Skripsi, Fakultas Teknik Univ. Muhammadiyah Jember, Jember.

[3] Yudistira, A., 2017, Uji Aktivitas Anti Campak dan rubella Ekstrak Daun Sesewanua Terhadap Sel Campak dan rubella, Jurnal Ilmiah Farmasi UNSRAT, No. 2, Vol. 6, Hal. 4551.

[4] Fatoni, C. S., Noviandha, F. D., 2017, Case Based Reasoning Diagnosis Penyakit Difteri dengan Algoritma K-Nearest Neighbor, Citec Journal, No. 3, Vol 4, Hal. 220 - 232

[5] Agusli, R., Sutarman., Suhendri., 2017, Sistem Pakar Identifikasi Tipe Kepribadian Karyawan Menggunakan Metode Certainty Factor, Jurnal Sisfotek Global, No. 1, Vol. 7, Hal. $21-27$

[6] Hamidi, R., Hengky, A., Pratiwi, H. S., 2017, Analisis Perbandingan Sistem Pakar dengan Metode Certainly Factor pada Penyakit Kelinci, Jurnal Sisem dan Teknologi Informasi (JUSTIN), No. 1, Vol 1, Hal. 142 - 147

[7] Singla, J., 2013, The Diagnosis of Some Lung Diseases in a Prolog Expert System, International Journal of Computer Applications, No. 15, Volume 78, Hal. 37 - 40. Kemenkes, 2019, Pedoman Pengendalian Terhadap Anak. Keputusan Menteri Kesehatan (KEMENKES) Republik Indonesia Nomor-856, Jakarta. 